\title{
$\therefore$ \\ IJCRR \\ Section: Healthcare \\ Progressive Insights into the Pharmacological Importance of Isoquinoline Derivatives in Modern Therapeutics
} ISI Impact Factor (2019-20): 1.628 IC Value (2019): 90.81 $\operatorname{SJIF}(2020)=7.893$

(c) (i) (3) Copyright@IJCRR

\author{
Kishor R. Danao${ }^{1}$, Pooja M. Malghadeㄹ, Debarshi Kar Mahapatra', \\ Meha N. Motiwala², Ujwala N. Mahajan ${ }^{3}$
}

'Department of Pharmaceutical Chemistry, Dadasaheb Balpande College of Pharmacy, Nagpur 440037, Maharashtra, India; 'Department of Pharmacognosy, Dadasaheb Balpande College of Pharmacy, Nagpur 440037, Maharashtra, India; ${ }^{3}$ Department of Quality Assurance, Dadasaheb Balpande College of Pharmacy, Nagpur 440037, Maharashtra, India.

\section{ABSTRACT}

Isoquinoline (ISOQ) is a heterocyclic aromatic organic compound composed of a benzene ring fused to a pyridine ring, referred to as benzopyridines. The chemical formula is $\mathrm{C} 9 \mathrm{H} 7 \mathrm{~N}$ with a molar mass of $129.162 \mathrm{~g} / \mathrm{mol}$. This ISOQ ring derives from the natural aromatic amino acid tyrosine. It is weak alkaline in nature but is more basic than quinoline. It appears as a yellowish oily liquid, having an unpleasant odour, hygroscopic when solid, has a density of $1.099 \mathrm{~g} / \mathrm{cm} 3$, a melting point of $26^{\circ} \mathrm{C}$ to $28^{\circ} \mathrm{C}\left(79^{\circ} \mathrm{F}\right.$ to $\left.82^{\circ} \mathrm{F}\right)$, the boiling point of $242^{\circ} \mathrm{C}\left(468^{\circ} \mathrm{F}\right)$, and dipole moment of 2.49 . In the preparation of this review article, a widespread examination of the published literature in varied pharmaceutical and medical databases such as PubMed, Google Scholar, etc. was fruitfully carried out and categorized consequently. The imperative review revealed the less known biological (anti-fungal, anti-Parkinsonism, anti-tubercular, anti-tumour, anti-glaucoma, anti-Alzheimer's disease, anti-viral, anti-bacterial, anti-diabetic, anti-malarial, etc.) potentials of ISOQ (an important class of chemical compounds) and their synthetic derivatives. This knowledge will serve as a ready reference for the global researchers and will be very helpful or inspiring for the medicinal chemists or associated investigators in developing novel low-molecular-weight (LMW) inhibitors for pharmacotherapeutic applications.

Key Words: Isoquinoline, Derivatives, Pharmacology, Therapeutics, Targets, Inhibitors

\section{INTRODUCTION}

Isoquinoline (ISOQ) is a heterocyclic aromatic organic compound composed of a benzene ring fused to a pyridine ring, referred to as benzopyridines (Figure 1). ${ }^{1}$ The chemical formula is $\mathrm{C}_{9} \mathrm{H}_{7} \mathrm{~N}$ with a molar mass of $129.162 \mathrm{~g} / \mathrm{mol}^{2}{ }^{2}$ It is a structural isomer of quinoline where the nitrogen atom is present on $2^{\text {nd }}$ position of the benzene ring. ${ }^{3}$ This ISOQ ring derives from the natural aromatic amino acid tyrosine. ${ }^{4}$ It is weak alkaline in nature but is more basic than quinoline. ${ }^{5}$ It appears as a yellowish oily liquid, having an unpleasant odour, hygroscopic when solid, has a density of $1.099 \mathrm{~g} / \mathrm{cm}^{3}$, a melting point of $26^{\circ} \mathrm{C}$ to $28^{\circ} \mathrm{C}\left(79^{\circ} \mathrm{F}\right.$ to $\left.82^{\circ} \mathrm{F}\right)$, the boiling point of $242^{\circ} \mathrm{C}\left(468^{\circ} \mathrm{F}\right)$, and dipole moment of $2.49{ }^{6-8}$ The dissolution of ISOQ is well in acetone, diethyl ether, carbon disulfide, and various organic solvents but is less soluble in water. Several studies have found that ISOQ is also soluble in dilute acids. ${ }^{9}$<smiles>c1ccc2cnccc2c1</smiles>

Figure 1: Structure of isoquinoline.

\section{SYNTHETIC APPROACHES}

Various synthesis protocols were reviewed regarding the development of ISOQ derivatives such as the Bischler-Napieralski reaction (Figure 2), Pictet-Spengler reaction, and Pomeranz-Fritsch reaction whereas several new methodology and modification has been reported time to time..$^{10,11}$ Overall, Pomeranz-Fritsch reaction is found to be the most efficient method for the compound preparation where amino acetoal-

\section{Corresponding Author:}

Kishor R. Danao, Assistant Professor, Department of Pharmaceutical Chemistry, Dadasaheb Balpande College of Pharmacy, Nagpur 440037, Maharashtra, India; Contact No.+91-9860282483; E-mail: kishordanao1982@gmail.com

ISSN: 2231-2196 (Print)

ISSN: 0975-5241 (Online)

Received: 12.09 .2020

Revised: 04.11 .2020

Accepted: 28.11 .2020

Published: 16.02 .2021 
dehyde diethyl acetal and benzaldehyde are made to react in acid medium. ${ }^{12}$ In contrast, the Schlittler-Muller synthesis involves the reaction of benzylamine with glyoxal acetal. Bischler-Napieralski reaction and Pictet-Spengler reaction are now taken into consideration by chemists for the production of substituted products. ${ }^{13,14}$ The substituted isoquinolines were generated by these methods such as dihydroisoquinolines and tetrahydroisoquinolines, which are produced in their oxidized analogues. ${ }^{15}$

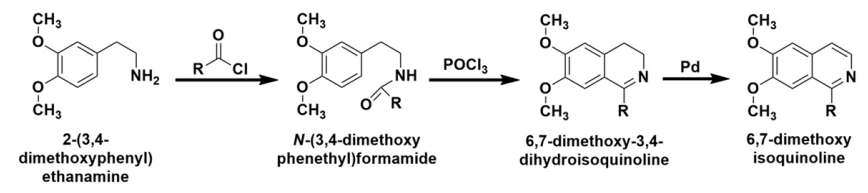

Figure 2: Bischler-Napieralski Reaction.

\section{PHARMACOLOGICAL POTENTIALS}

ISOQ and their derivatives occur in various natural products and are considered pharmacologically active owing to their potentials in expressing a large number of biological activities like anti-malarial, anti-HIV, anti-tumour, anti-fungal, anti-fungal, anti-tubercular, anti-glaucoma, anti-bacterial, anti-Parkinson's disease, etc (Figure 3). ${ }^{16-18}$ They are used in the manufacture of paints, dyes, and insecticides. ${ }^{19}$ They are employed as a solvent for the extraction of resin and terpenes. $^{20}$

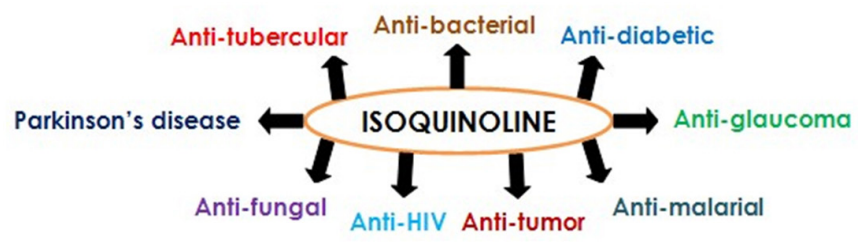

Figure 3: Therapeutic applications of Isoquinoline compounds.

\section{Anti-fungal Activity}

The fungal infections are life-threatening opportunistic infections that are an increasingly important cause of illness in patients, principally individuals having weak immune power or hospitalized with stern fundamental ailments. ${ }^{21,22}$ The majority of these infections are caused by Candida spp., with over $50 \%$ due to Candida albicans, a diploid fungus that grows both on yeast and filamentous. ${ }^{23}$ These fungi are responsible for various forms of the disease, ranging from superficial infections of the mucosal surfaces or skin to systemic infections, in most cases which is life-threatening. ${ }^{24}$ Siwek et al. synthesized and evaluated in vitro anti-fungal potency of 4-arylthiosemicarbazides series. Two different mechanisms of anti-fungal activity related to thiosemicar- bazide derivatives have been documented. The most potent candidates were found to be ortho-methoxy or ortho-methyl group at the phenyl ring. ${ }^{25}$ Antimycotic drugs can be also be resisted by various fungal species. Surikova et al. synthesized a series of (2,2-dimethyl-1,2,3,4-tetrahydro-benzo[f] isoquinolin-4-yl)thioacetic acid which showed remarkable anti-fungal activity. ${ }^{26}$

Cantrell et al. synthesized two agrochemical agents; sanguinarine (Compound 1) and chelerythrine (Compound 2) and investigated the in vitro antifungal potential against Rhizoctonia solani. These alkaloids demonstrated potent fungicidal activity with sanguinarine as the most effective candidate. ${ }^{27}$

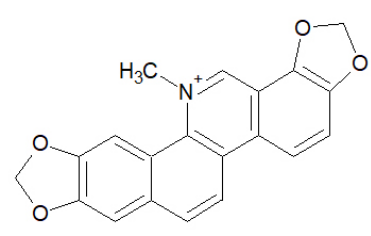

(Compound 1)

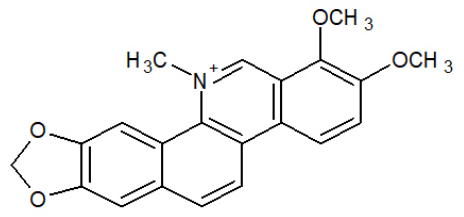

(Compound 2)

\section{Anti-Parkinson's Activity}

In this disease, substantia nigra includes progressive degeneration of dopaminergic neurons. ${ }^{28}$ The derivatives of 1,2,3,4-tetrahydroisoquinoline (TIQ) and 1-methyl-4-phenyl-1,2,3,6-tetrahydropyridine (MPTP) are employed in Parkinsonism disorder in an animal model owing to the structural similarities with an endogenous neurotoxin that have been studied for symptoms. ${ }^{29}$ Several TIQ derivatives like 1-methyl-TIQ, $(R)$-1,2-dimethyl-5,6-dihydroxy-TIQ [ $(R)-\mathrm{N}$ methyl-salsolinol)], etc. have been into applications against behavioural abnormalities. ${ }^{30}$

The ISOQ are homologs with MPTP and have linkage with dopaminergic cell death in Parkinson's disease. ${ }^{31}$ The known defects in the patients such as MAO and $\alpha$-ketoglutarate are inhibited by TIQs and dihydroisoquinolines which are members of ISOQ derivatives. ${ }^{32}$ Natural substances of plants and several foods such as cheese, milk, banana, and cocoa also come under TIQ derivatives. ${ }^{33,34}$ Therefore, these TIQ derivatives are considered to prevent Parkinson's disease.

\section{Anti-tubercular Activity}

Mycobacterium tuberculosis is a bacterium that is responsible for a contagious disease, an infection called tuberculosis (TB). ${ }^{35}$ This disease has a high rate of mortality in the world where about 3 million people die every year and 8 million new cases are estimated each year in $95 \%$ of developing nations. ${ }^{36}$ The current therapy includes the combination (Isoniazid, Rifampin, or Pyrazinamide) for 2 months, followed by 4 months of follow-up therapy with isoniazid and rifampin. ${ }^{37}$ However, due to the arising of multidrug-resistant (MDR)-TB, the development of new therapeutic agents with 
a unique mechanism of action are required for treating these MDR forms. ${ }^{38,39}$

Benzo[g]isoquinoline-5,10-diones were synthesized from 2-methyl-1,4-naphthoquinone and screened against virulent strain where higher anti-tubercular potency was observed for derivatives having position-3 substitution. The minimal inhibition concentrations (MICs) of these compounds lie in the range of $1.05 \mu \mathrm{M}$ to $28.92 \mu \mathrm{M}$, respectively along with acute cytotoxic concentrations of $>128 \mu \mathrm{M}^{40}$

\section{Anti-tumour Activity}

ISOQ has been identified as bioactive ingredients in natural products-based therapeutics. ISOQs exhibit potential anti-cancer activity which makes them an important basis for treating cellular proliferation. ${ }^{41}$ Liu et al. evaluated the anti-neoplastic activity of various substituted isoquinoline1-carboxyaldhyde thiosemicarbazones (Compound 3) where 4-amino and 4-(methylamino) have been identified as potential candidates. ${ }^{42,43}$

Current chemotherapies for cancer are mostly cytotoxics with serious side-effects and high incidence of drug resistance which escalated the need for new anti-tumour agents with reduced toxicity, excellent stability, significant anticancer activity, and increased efficacy. ${ }^{44,45}$ Because of the ability of human transferrin to undergo receptor-mediated endocytosis, it has been used previously for targeting the LP's. ${ }^{46}$

Derivatives of isoquinoline and $\alpha$-methylene- $\gamma$ butyrolactones were screened using the 3-(4,5-dimethylthiazol-2-yl)-2,5-diphenyltetrazolium bromide (Compound 4) which was identified as the most potent anti-cancer agent. ${ }^{47}$ There are several kinds of biological activities such as an anti-Trypanosoma cruzi, an antibiotic tryptanthrin, and a cytotoxic luotonin which comprised of benzimidazoisoquinoline structure. ${ }^{48,49}$

The anti-cancer potential of [1,2,4]-triazolo[3,4-a]isoquinolines and pyrrolo[2,1a]isoquinolines have been identified in the past few years. For the synthesis of some anti-tumour (anti-leukemic, tubulin polymerization properties) alkaloids like lamellarins and crysrinepyrrolo, [2,1-a]isoquinoline serves as an intermediate. ${ }^{50}$ For the inhibition of estrogen (ER) receptors, acetoxysubstituted 5,6-dihydropyrrolo[2,1a]isoquinoline (Compound 5) serves a major role. ${ }^{51}$ Also, isoquinoline derivatives like Lamellarin $\mathrm{D}$ act as a potent topoisomerase-I inhibitor and induce apoptosis through the mitochondria-mediated pathway towards cancer cell lines. ${ }^{52}$

Tamoxifen, the selective estrogen receptor modulators (SERMs) is employed for treating breast cancer that works by preventing the binding of estrogen to the estrogen receptors and thereby slowing down the estrogen-induced cellular proliferation..$^{53,54}$ Newly introduced pyrrolo[2,1-a]-isoquinoline derivatives and 1,2-diaryl-5,6-dihydropyrolo[2,1a]- isoquinoline derivatives (Compound 6) have shown better suppression of breast cancer as compared to the standard tamoxifen. ${ }^{55}$

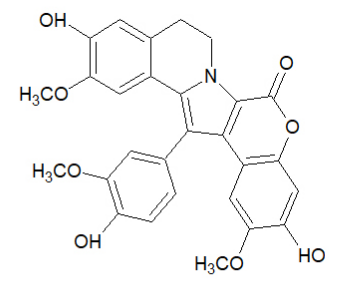

(Compound 3)

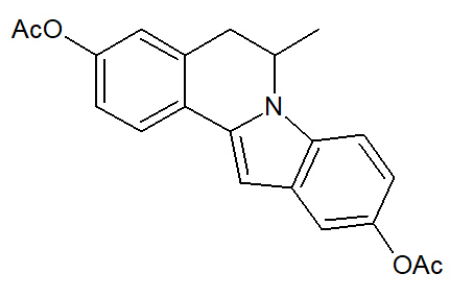

(Compound 5)

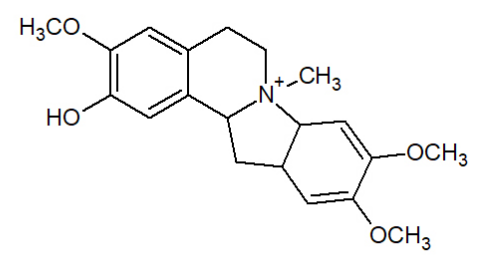

(Compound 4)

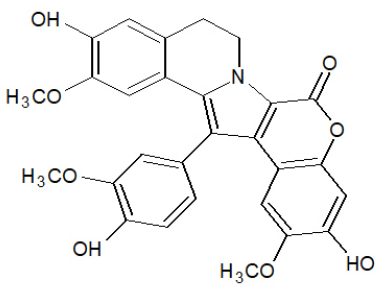

(Compound 6)

\section{Anti-glaucoma}

Most of the surveys on glaucoma have reported that after cataract, it is the second leading cause of blindness worldwide. ${ }^{56}$ ISOQ sulphonamides-based moderate Rho-kinase Inhibitors; Fasudil (Compound 7) has been successfully evaluated for clinical studies. ${ }^{57,58}$ It is oxidized in vivo to hydroxyfasudil (Compound 8) which is slightly more active than the corresponding drug. Further, optimizations (methyl substituents at 4-position and 2-position in the ISOQ scaffold) of the compound led to the development of a compound with improved potency; dimethylfasudil (Compound 9). ${ }^{59,60}$ By varying the position of the methyl group the effect of methylation on the homopiperazine ring was studied. Compound 10 with an unsubstituted homopiperazine ring and compounds (Compounds 11-13) with homopiperazine ring substituted with a methyl group at 3-position, 5-position, and 6-position exhibited a very low potency towards Rho-kinase II. Methylation at 7-position of the ring (Compound 14) showed potent inhibition against Rho-kinase II. However, methyl substitution at 2-position of the homopiperazine ring was found to be most ideal in terms of selectivity as well as potency. ${ }^{61,62}$

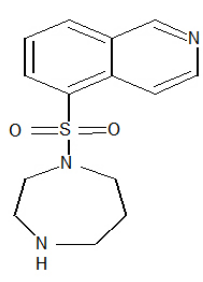

(Compound 7)

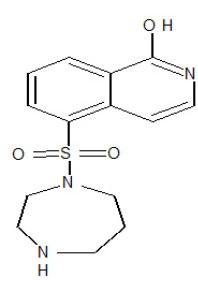

(Compound 8)

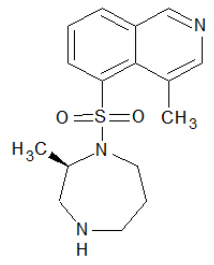

(Compound 9) 


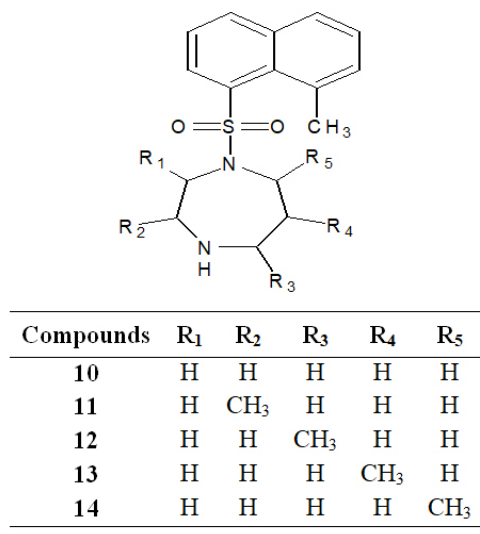

\section{Anti-Alzheimer's Disease}

Alzheimer's disease (AD) is an age-related, progressive, neurodegenerative disorder, with onset usually in later ages (65 years to 85 years) ${ }^{63} \mathrm{AD}$ has two characteristic pathological hallmarks; extracellular accumulation of $\beta$-amyloid peptide (amyloid plaques), and intraneuronal formation of hyperphosphorylated $\tau$-protein filaments leading to progressive loss of neurons and disintegration of the neural circuits, particularly in the cerebral cortex. ${ }^{64}$ Use of the currently available drugs in $\mathrm{AD}$ correlate with dementia severity and mostly relies on the cholinergic hypothesis that decreases in cholinergic transmission in the neocortex and hippocampus. ${ }^{65,66}$

Various NMDA blockers and cholinesterase inhibitors (ChEIs) are under clinical trials. ${ }^{67}$ The United States Food and Drug Administration (USFDA) has approved donepezil, galanthamine, and rivastigmine to treat the symptoms of Alzheimer's disease. ${ }^{68}$ Galanthamine and donepezil are taken as selective AChE inhibitors, while rivastigmine is a dual inhibitor of cholinesterases. ${ }^{69}$ As discussed above, both $\mathrm{AChE}$ and $\mathrm{BChE}$ are responsible for the breakdown of $\mathrm{ACh}$ in the synapses. Therefore, the inhibition of both enzymes represents a beneficial approach in $\mathrm{AD}$ treatment. ${ }^{70,71}$ Laudanosine (Compound 15), Protopine (Compound 16), Allocryptopine (Compound 17), Argemonine (Compound 18), Platycerine (Compound 19), Munitagine (Compound 20), and Norargemonine (Compound 21) have been identified as potential ISOQ and ISOQ-based derivatives with potential anti-Alzheimer's disease.<smiles>COc1ccc(C[C@H]2c3cc(OC)c(OC)cc3CCN2C)cc1OC</smiles>

(Compound 15)<smiles>[R]c1ccc(CC(=O)c2cc3c(cc2CCN(C)C)COCO3)c([R])c1[R]</smiles>

(Compound 16) $\mathrm{R}^{1}=\mathrm{R}^{2}=\mathrm{OCH}_{2} \mathrm{O}\left(\right.$ Compound 17) $\mathrm{R}^{1}=\mathrm{R}^{2}=\mathrm{OCH}_{3}$

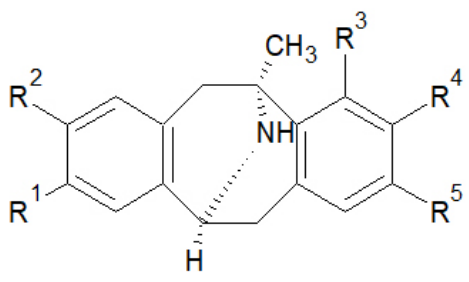

\begin{tabular}{cccccc}
\hline Compounds & $\mathbf{R}^{\mathbf{1}}$ & $\mathbf{R}^{2}$ & $\mathbf{R}^{3}$ & $\mathbf{R}^{4}$ & $\mathbf{R}^{5}$ \\
\hline $\mathbf{1 8}$ & $-\mathrm{OCH}_{3}$ & $-\mathrm{OCH}_{3}$ & $-\mathrm{H}$ & $-\mathrm{OCH}_{3}$ & $-\mathrm{OCH}_{3}$ \\
$\mathbf{1 9}$ & $-\mathrm{OCH}_{3}$ & $-\mathrm{OCH}_{3}$ & $-\mathrm{OH}$ & $-\mathrm{OCH}_{3}$ & $-\mathrm{H}$ \\
$\mathbf{2 0}$ & $-\mathrm{OH}$ & $-\mathrm{OCH}_{3}$ & $-\mathrm{OH}$ & $-\mathrm{OCH}_{3}$ & $-\mathrm{H}$ \\
$\mathbf{2 1}$ & $-\mathrm{OH}$ & $-\mathrm{OCH}_{3}$ & $-\mathrm{H}$ & $-\mathrm{OCH}_{3}$ & $-\mathrm{OCH}_{3}$ \\
\hline
\end{tabular}

\section{Anti-viral Activity}

Bedard et al. demonstrated anti-viral activity of 1,6-naphthyridine ISOQ derivatives against human cytomegalovirus (HCMV) where excellent results have been observed..$^{72}$ The selected compounds were characterized by the presence of a 1,6-naphthyridine (Compound 22) or a dihydroisoquinoline (Compounds 23-24). ${ }^{73}$ Compound 2 with a dihydroisoquinoline scaffold was found to be less potent than ganciclovir (GCV) whereas Compound 3 was 3-times to 9-times more active than GCV. The naphthyridine derivative (Compound 22) was found to have the highest HCMV activity with an $\mathrm{IC}_{50}$ of 39 -fold to 223 -fold lower than $\mathrm{GCV} .{ }^{74}$

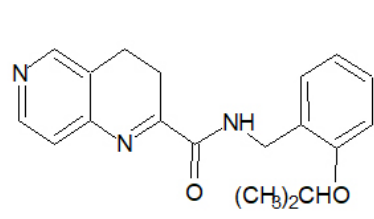

(Compound 22)

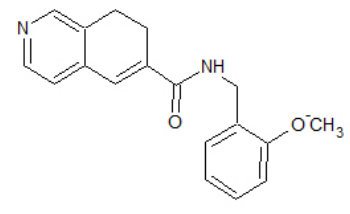

(Compound 23)

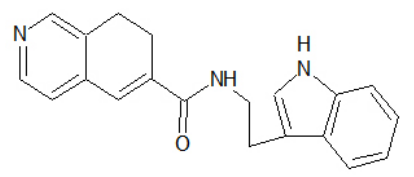

(Compound 24)

\section{Anti-bacterial Activity}

There are ISOQ alkaloids with potent anti-microbial activities which encouraged the synthesis new antimicrobial 
compounds such as 1-pentyl-6,7-dimethoxy-1,2,3,4-tetrahydroisoquinolines (THIQs) with dihyroisoquinolinium salts, chlorobenzoates, methyl pentanoate-THIQ, fluorophenylpropanoate/chlorophenylpropanoate ester, phenethyl/chlorophenethyl carbamates, halogenated phenyls, 1-pentanolTHIQ, and carbamates derivatives have been developed for bactericidal and fungicidal activities. ${ }^{75-77}$

Nord et al. isolated new anti-bacterial secondary metabolites; 6,7-dihydroxy-5,10-dihydropyrrolo[1,2-b]isoquinoline-3-carboxylic acid, Spathullin A (Compound 25) and 5,10-dihydropyrrolo[1,2-b]isoquinoline-6,7-diol, Spathullin B (2) from culture broths of Penicillium spathulatum and screened against both Gram-negative and Gram-positive species like E. coli., A. baumannii, E. cloacae, K. pneumonia, $P$. aeruginosa, and $S$. aureus. Compound 25 was identified as less potent but more cytotoxic than Compound 26 . The biosynthesis of Compound $\mathbf{2 5}$ was suggested to proceed from cysteine, tyrosine, and methionine via an enzyme that is a non-ribosomal peptide synthetase. ${ }^{79}$<smiles>O=C(O)C1=CCC2Cc3ccc(O)c(O)c3CN12</smiles>

(Compound 25)

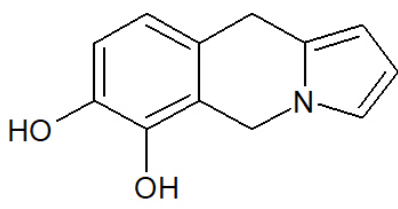

(Compound 26)

\section{Anti-diabetic Activity}

Type-2 diabetes mellitus (T2DM) morbidity and mortality is increasing worldwide and is the rising form of $\mathrm{DM}^{80}$ The biggest challenge in the modern era is the management or treatment and healing the complication associated with T2DM. Berberine (BBR) is an ISOQ-based natural product extracted from Coptis chinensis known to have glucose reducing properties by mitochondrial respiratory chain complex-I suppression mechanism (via activation of the AMPK signalling pathway), which simultaneously stimulates glycolysis (decreases the rate of protons pumped from matrix to inner membrane space) and consumption of glucose (consequently lowers the mitochondrial membrane potential) ${ }^{81}$

BBR derivatives were created by Zhang et al. and were evaluated for glucose-lowering potentials (promoting glucose consumption) where derivatives possessing amide bond and amidogen at 9-position better potency than parent BBR. ${ }^{82}$ Recently, accumulating evidence has indicated that BBR synthetic analogues have displayed high anti-diabetic activities and anti-hyperlipidemic activities which lead to an enhanced interest in their applications. ${ }^{83,84}$ Ren et al. discovered that dihydroberberine (dhBBR) (Compound 27) had better in vivo hypoglycemic efficacy in high-fat-fed rodents, enhanced oral bioavailability, and analogous potency com- pared with BBR by similar pathway. ${ }^{85}$ Cheng et al. designed and synthesized 8,8-dimethyldihydroberberine (Compound 28 ) which showed improved bioavailability and oral efficacy as compared to dhBBR via analogous mechanism. ${ }^{86}$

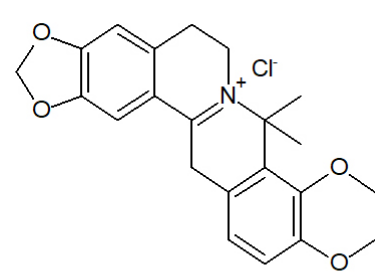

(Compound 27)

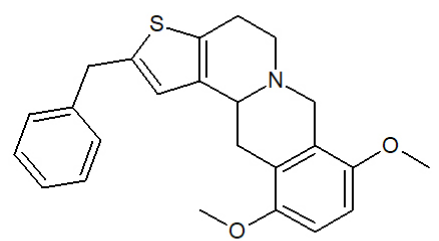

(Compound 28)

\section{Anti-malarial Activity}

Angustureine (Compound 29), galipeine (Compound 30), cuspareine (Compound 31), and galipinine (Compound 32), obtained from the bark extract of Galipea Officinalis, commonly known as "angostura", belongs to the group of 2-alkyl1-methyl-1,2,3,4-tetrahydroquinoline naturally occurring alkaloid. ${ }^{87,88}$ Due to the stereogenic centre at position-2, they are chiral active molecules. Among the 20 species of Galipea genus, the shrub G. Officinalis is known ethnobotanically for treating dyspepsia, dysentery, chronic diarrhoea, and mainly shows anti-malarial activity. ${ }^{89}$

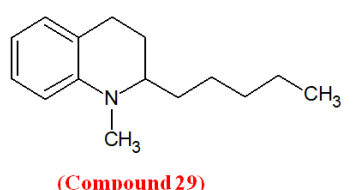

(Compound 29)

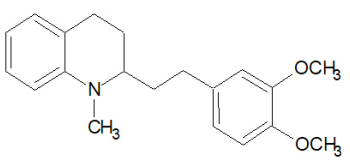

(Compound 31)

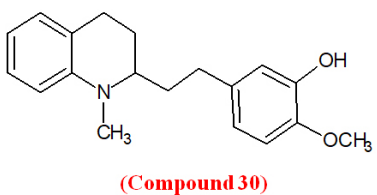

(Compound 30)

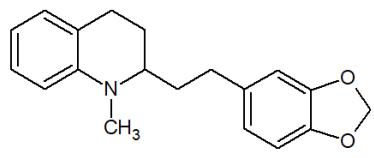

(Compound 32)

\section{CONCLUSION}

The imperative review revealed the less known biological (anti-fungal, anti-Parkinsonism, anti-tubercular, anti-tumour, anti-glaucoma, anti-Alzheimer's disease, anti-viral, anti-bacterial, anti-diabetic, anti-malarial, etc.) potentials of ISOQ (an important class of chemical compounds) and their synthetic derivatives. This knowledge will serve as a ready reference for the global researchers and will be very helpful or inspiring for the medicinal chemists or associated investigators in developing novel low-molecular-weight (LMW) inhibitors for pharmacotherapeutic applications.

\section{Conflict of Interest}

Authors declare no conflict of interest regarding the publication of this article. 


\section{Funding Information}

No funding agency or sources acknowledged.

\section{ACKNOWLEDGEMENT}

The authors acknowledge the college management for kind support and research aids.

\section{AUTHORS CONTRIBUTION}

KRD: Physically authored the whole manuscript

PMM: Complete literature survey performed

DKM: Made all Figures, Wrote Structured Abstract, Drawn Graphical Abstract, Set References

MNM: Final reviewing of this manuscript

UNM: Provided suggestions and corrected few errors

\section{REFERENCES}

1. Harris J, Pope WJ. Isoquinoline and the isoquinoline-reds. $\mathrm{J}$ Chem Soc 1922;121:1029-1033.

2. Pozharskii AF, Soldatenkov AT, Katritzky AR. Heterocycles in life and society: an introduction to heterocyclic chemistry, biochemistry and applications. John Wiley \& Sons; 2011.

3. Katritzky AR, Pozharskii AF, Soldatenkov A. Heterocycles in Life and Society: An Introduction to Heterocyclic Chemistry, Biochemistry and Applications. John Wiley \& Sons; 2011.

4. Khan F, Qidwai T, Shukla RK, Gupta V. Alkaloids Derived from Tyrosine: Modified Benzyltetrahydroisoquinoline Alkaloids. Nat Prod 2013;8(3):405-460.

5. Gilchrist TL. Heterocyclic chemistry. Addison Wesley Longman, UK; 1997.

6. O’Neil, Maryadele J. The Merck Index. Whitehouse Station; 2001.

7. Quinoline. Encyclopedia Britannica. 1911;11(22): 758-759.

8. Ram VJ, Sethi A, Nath M, Pratap R. The Chemistry of Heterocycles: Nomenclature and Chemistry of Three to Five Membered Heterocycles. Elsevier; 2019.

9. Braude EA, Nachod FC. Determination of organic structures by physical methods. Elsevier; 2013.

10. Jie JL. Name Reactions: A Collection of Detailed Mechanisms and Synthetic Applications. Springer Science Ltd.; 2014.

11. Wang Y, Patil P, Kurpiewska K, Kalinowska-Tluscik J, Dömling A. Diverse Isoquinoline Scaffolds by Ugi/Pomeranz-Fritsch and Ugi/Schlittler-Müller Reactions. Org Lett 2019;21(10):35333537.

12. Marella A, Tanwar OP, Saha R, Ali MR, Srivastava S, Akhter M, Shaquiquzzaman M, Alam MM. Quinoline: A versatile heterocyclic. Saudi Pharm J 2013;21(1):1-2.

13. Pandeya SN, Tyagi A. Synthetic approaches for quinoline and isoquinoline. ChemInform 2012;43(3):5361-5365.

14. Lass-Flörl C. The changing face of epidemiology of invasive fungal disease in Europe. Mycoses 2009;52(3):197-205.

15. Palomino JC, Martin A. Drug Resistance Mechanisms in Mycobacterium tuberculosis. Antibiotics 2014,3(3):317-340.

16. Kakhkia S, Shahosseinia S, Zarghi A. Pyrrolo[2,1-a] Isoquinoline-Based Derivatives as New Cytotoxic Agents, Iranian J Pharm Res 2016;15(4):743-751.
17. Heravi M, Nazari N. Bischler-Napieralski reaction in total synthesis of isoquinoline-based natural products. An old reaction, a new application. Curr Org Chem 2015;19(24):2358-2408.

18. Pashev AS, Burdzhiev NT, Stanoeva ER. Synthetic Approaches toward the Benzo [a] quinolizidine System. A Review. Org Prep Proced Int 2016;48(6):425-467.

19. Awuah E, Capretta A. Strategies and synthetic methods directed toward the preparation of libraries of substituted isoquinolines. J Org Chem 2010;75(16):5627-5634.

20. Zheng B, Trieu TH, Li FL, Zhu XL, He YG, Fan QQ, Shi XX. Copper-Catalyzed Benign and Efficient Oxidation of Tetrahydroisoquinolines and Dihydroisoquinolines Using Air as a Clean Oxidant. ACS Omega 2018;3(7):8243-8252.

21. Pfaller MA, Diekema DJ. Epidemiology of invasive candidiasis: a persistent public health problem. Clin Microbiol Rev 2007;20(1):133-163.

22. Negri M, Martins M, Henriques M, Svidzinski TI, Azeredo J, Oliveira R. Examination of potential virulence factors of Candida tropicalis clinical isolates from hospitalized patients. Mycopathologia 2010;169(3):175-182.

23. Baron S. Alphaviruses (Togaviridae) and Flaviviruses (Flaviviridae)--Medical Microbiology. University of Texas Medical Branch at Galveston; 1996.

24. Borg-von ZM, Kunz L, Ruchel R, Reichard U, Weig M, Gross U. Epidemiology and antifungal susceptibilities of Candida spp. to six antifungal agents. Antimicrob Chemother 2007;60:424-428.

25. Siwek A, Stefańska J, Dzitko K, Ruszczak A. Antifungal effect of 4-arylthiosemicarbazides against Candida species. Search for molecular basis of antifungal activity of thiosemicarbazide derivatives. J Mol Model 2012;18(9):4159-4170.

26. Surikova OV, Zachinyaeva AV, Mikhailovskii AG, Zachinyaev YV. Synthesis of 2, 2-dimethyl-1, 2-dihydrobenzo [f]-isoquinolines displaying antifungal activity. Chem Heterocycl Compd 2011;46(12):1471-1475.

27. Cantrell CL, Dayan FE, Duke SO. Natural products as sources for new pesticides. J Nat Prod 2012;75(6):1231-1242.

28. Walton JN. Brain's Diseases of the Nervous System. Oxford: Oxford University Press; 1977.

29. Abe K, Saitoh T, Horiguchi Y, Utsunomiya I, Taguchi K. Synthesis and Neurotoxicity of Tetrahydroisoquinoline Derivatives for Studying Parkinson's Disease. Biol Pharm Bull 2005;28(8):1355-1362.

30. Ishiwata K, Koyanagi Y, Abe K, Kawamura K, Taguchi K, Saitoh T, Toda J, Senda M, Sano T. Evaluation of neurotoxicity of TIQ and MPTP and of parkinsonism-preventing effect of 1-MeTIQ by in vivo measurement of pre-synaptic dopamine transporters and post-synaptic dopamine D2 receptors in the mouse striatum. J Neurochem 2001;79(4):868-876.

31. Nagatsu T. Isoquinoline neurotoxins in the brain and Parkinson's disease. Neurosci Res 1997;29(2):99-111.

32. Bembenek ME, Abell CW, Chrisey LA, Rozwadowska MD, Gessner W, Brossi A. Inhibition of monoamine oxidases A and B by simple isoquinoline alkaloids: racemic and optically active 1, 2, 3, 4-tetrahydro-, 3, 4-dihydro-, and fully aromatic isoquinolines. J Med Chem 1990;33(1):147-152.

33. Antkiewicz-Michaluk L, Wąsik A, Michaluk J. 1-Methyl1,2,3,4-tetrahydroisoquinoline, an endogenous amine with the unexpected mechanism of action: new vistas of therapeutic application. Neurotox Res 2013;25(1):1-12.

34. Storch A, Ott S, Hwang YI, Ortmann R, Hein A, Frenzel S, et al. Selective dopaminergic neurotoxicity of isoquinoline derivatives related to Parkinson's disease: studies using heterologous expression systems of the dopamine transporter. Biochem Pharmacol 2002;63(5):909-920. 
35. Smith I. Mycobacterium tuberculosis pathogenesis and molecular determinants of virulence. Clin Microbiol Rev 2003;16(3):463-496.

36. Andersen P. TB vaccines: progress and problems. Trends Immunol 2001;22:160-168.

37. Barnes DS. Historical perspectives on the aetiology of tuberculosis. Microb Infect 2000;2(4):431-440.

38. Brosch R, Gordon SV, Marmiesse M, Brodin P, Buchrieser C, Eiglmeier K, Garnier T, Gutierrez C, Hewinson G, Kremer K, Parsons LM. A new evolutionary scenario for the Mycobacterium tuberculosis complex. Proc Natl Acad Sci 2002;99:36843689.

39. Dookie N, Rambaran S, Padayatchi N, Mahomed S, Naidoo $\mathrm{K}$. Evolution of drug resistance in Mycobacterium tuberculosis: a review on the molecular determinants of resistance and implications for personalized care. J Antimicrob Chemother 2018;73(5):1138-1151.

40. Smets RJ, Torfs E, Lemière F, Cos P, Cappoen D, Tehrani KA. Synthesis and antitubercular activity of 1-and 3-substituted benzo [g] isoquinoline-5, 10-diones. Org Biomol Chem 2019;17(11):2923-2939.

41. Jain S, Chandra V, Jain PK, Pathak K, Pathak D, Vaidya A. Comprehensive review on current developments of quinoline-based anticancer agent. Arabian J Chem 2019;12(8):4920-4946.

42. Liu MC, Lin TS, Penketh P, Sartorelli AC. Synthesis and antitumor activity of 4-and 5-substituted derivatives of isoquinoline-1-carboxaldehyde thiosemicarbazone. J Med Chem 1995;38(21):4234-4243.

43. Liu MC, Lin TS, Sartorelli AC Chemical and biological properties of cytotoxic alpha-(N)-heterocyclic carboxaldehyde thiosemicarbazones. Prog Med Chem 1995;32:1-35.

44. Wang X, Zhang H, Chen X. Drug resistance and combating drug resistance in cancer. Cancer Drug Resist 2019;2:141-160.

45. Janecka A, Wyrębska A, Gach K, Fichna J, Janecki T. Natural and synthetic $\alpha$-methylenelactones and $\alpha$-methylenelactams with anticancer potential. Drug Discov Today 2012;17(1112):561-572.

46. Yang X, Yang S, Chai H, Yang Z, Lee RJ, Liao W, et al. A novel isoquinoline derivative anticancer agent and its targeted delivery to tumour cells using transferrin-conjugated liposomes. PLoS One 2015;10(8):e0136649.

47. Yan Y, En D, Zhuang Z, Guo Y, Liao WW. Synthesis of densely functionalized $\alpha$-methylene $\gamma$-butyrolactones via an organocatalytic one-pot allylic-alkylation-cyclization reaction. Tetrahedron Lett 2014;55(2):479-482.

48. Bollini M, Casal JJ, Alvarez DE, Boiani L, González M, Cerecetto $\mathrm{H}$, et al. New potent imidazoisoquinolinone derivatives as anti-Trypanosoma cruzi agents: biological evaluation and structure-activity relationships. Bioorg Med Chem 2009;17(4):14371444.

49. Liao WL, Li SQ, Wang J, Zhang ZY, Yang ZW, Xu D, et al. An efficient and facile method for the synthesis of benzimidazoisoquinoline derivatives via a multicomponent reaction. ACS Comb Sci 2016;18(1):65-69.

50. Bailly C. Anticancer Properties of Lamellarins. Mar Drugs 2015;13(3):1105-1123.

51. Kakhki S, Shahosseini S, Zarghi A. Design and synthesis of pyrrolo $[2,1-\mathrm{a}]$ isoquinoline-based derivatives as new cytotoxic agents. Iranian J Pharm Res 2016;15(4):743.

52. Facompré M, Tardy C, Bal-Mahieu C, Colson P, Perez C, Manzanares I, et al. A novel potent inhibitor of topoisomerase I. Cancer Res 2003;63(21):7392-7399.

53. Jiang M, Huang O, Zhang X, Xie Z, Shen A, Liu H, et al. Curcumin induces cell death and restores tamoxifen sensitivity in the antiestrogen-resistant breast cancer cell lines MCF-7/LCC2 and MCF-7/LCC9. Molecules 2007;18:701-720.

54. Yue W, Wang JP, Li Y, Fan P, Liu G, Zhang N, Conaway M, Wang H, Korach KS, Bocchinfuso W, Santen R. Effects of estrogen on breast cancer development: Role of estrogen receptorindependent mechanisms. Int J Cancer 2010;127(8):1748-1757.

55. Kakhki S, Shahosseini S, Zarghi A. Design, synthesis and cytotoxicity evaluation of new 2-aryl-5, 6-dihydropyrrolo[2, 1-a]isoquinoline derivatives as topoisomerase inhibitors. Iran J Pharm Res 2014,13:71-77.

56. Kingman S. Glaucoma is the second leading cause of blindness globally. Bull World Health Org. 2004;82:887-888.

57. Feng Y, Lograsso PV, Defert O. Rho kinase (ROCK) inhibitors and their therapeutic potential. J Med Chem 2016;59(2):269300 .

58. Oliveira RG, Guerra FS, Mermelstein CD, Fernandes PD, Bastos IT, Costa FN, et al. Synthesis and pharmacological evaluation of novel isoquinoline N-sulphonylhydrazones designed as ROCK inhibitors. J Enzyme Inhib Med Chem 2018;33(1):1181-1193.

59. Tanna AP, Johnson M. Rho-kinase inhibitors as a novel treatment for glaucoma and ocular hypertension. Ophthalmology 2018;125(11):1741-1756.

60. Wang SK, Chang RT. An emerging treatment option for glaucoma: Rho kinase inhibitors. Clin Ophthalmol 2014;8:883-890.

61. Mérour JY, Buron F, Plé K, Bonnet P, Routier S. The azaindole framework in the design of kinase inhibitors. Molecules. 2014;19(12):19935-19979.

62. Angeli A, Chiaramonte N, Manetti D, Romanelli MN, Supuran $\mathrm{CT}$. Investigation of piperazines as human carbonic anhydrase I, II, IV and VII activators. J Enzyme Inhib Med Chem 2018;33(1):303-308.

63. Lane CA, Hardy J, Schott JM. Alzheimer's disease. Eur J Neurol 2018;25:59-70.

64. Rajmohan R, Reddy PH. Amyloid-beta and phosphorylated tau accumulations cause abnormalities at synapses of Alzheimer's disease neurons. J Alzheimer's Dis 2017;57(4):975-999.

65. Nordberg A, Ballard C, Bullock R, Darreh-Shori T, Somogyi M. A review of butyrylcholinesterase as a therapeutic target in the treatment of Alzheimer's disease. Prim Care Companion CNS Disord 2013;15(2):PCC.12r01412.

66. Anand R, Gill KD, Mahdi AA. Therapeutics of Alzheimer's disease: Past, present and future. Neuropharmacology 2014;76:2750.

67. Ehret MJ, Chamberlin KW. Current practices in the treatment of Alzheimer disease: Where is the evidence after the phase III Trials. Clin Ther 2015;37:1604-1616.

68. Lleo A. Current therapeutic option for Alzheimer's disease. Curr Genom 2007;8:550-558.

69. Kumar S. Dual inhibition of acetylcholinesterase and butyrylcholinesterase enzymes by allicin. Indian J Pharmacol 2015;47(4):444-446.

70. Lane RM, Potkin SG, Enz A. Targeting acetylcholinesterase and butyrylcholinesterase in dementia. Int J Neuropsychopharmacol 2006;9:101-124.

71. Giacobini E. Cholinesterase inhibitors: new roles and therapeutic alternatives. Pharmacol Res 2004;50:433-440.

72. Bedard J, May S, Heurex L, Stamminger T, Chan L. Antiviral properties of a series of 1,6-naphthyridine and 7,8-dihydro isoquinoline derivatives exhibiting potent activity against human cytomegalovirus. Antimicrob Agent Chemother 2000;44:929937.

73. Chan L, Jin H, Stefanac T, Lavallée JF, Falardeau G, Wang W, Bédard J, et al. Discovery of 1, 6-naphthyridines as a novel class of potent and selective human cytomegalovirus inhibitors. J Med Chem 1999;42(16):3023-3025. 
74. Chan L, Jin H, Stefanac T, Wang W, Lavallée JF, Bédard J, et al. Isoquinoline-6-carboxamides as potent and selective anti-human cytomegalovirus (HCMV) inhibitors. Bioorg Med Chem Lett. 1999;9(17):2583-6.

75. Galán A, Moreno L, Párraga J, Serrano Á, Sanz MJ, Cortes D, et al. Novel isoquinoline derivatives as antimicrobial agents. Bioorg Med Chem 2013;21(11):3221-3230.

76. Galán A, Moreno L, Párraga J, Serrano Á, Sanz MJ, Cortes D, Cabedo N. Novel isoquinoline derivatives as antimicrobial agents. Bioorg Med Chem 2013;21(11):3221-3230.

77. Sloop JC. Advances in the Preparation of Fluorinated Isoquinolines: A Decade of Progress. J Chem 2017;2017.

78. Nord C, Levenfors JJ, Bjerketorp J, Sahlberg C, Guss B, Öberg B, Broberg A. Antibacterial Isoquinoline Alkaloids from the Fungus Penicillium Spathulatum Em19. Molecules 2019;24(24):4616.

79. Srivastava A, Talaue M, Liu S, Degen D, Ebright RY, Sineva E, et al. New target for inhibition of bacterial RNA polymerase: 'switch region'. Curr Opin Microbiol 2011;14(5):532-543.

80. Seuring T, Archangelidi O, Suhrcke M. The economic cost of type 2 diabetes: a global systematic review. Pharmacoeconomics 2015;33:811-831.

81. Lee YS, Kim WS, Kim KH, Yoon MJ, Cho HJ, Shen Y, et al. Berberine, a natural plant product, activates AMP-activated protein kinase with beneficial metabolic effects in diabetic and insulin-resistant states. Diabetes 2006;55:2256-2264.

82. Zhang H, Wei J, Xue R, Wu JD, Zhao W, Wang ZZ, et al. Berberine lowers blood glucose in type 2 diabetes mellitus patients through increasing insulin receptor expression. Metabolomics 2010;59:285-292.
83. Yin J, Gao Z, Liu D, Liu Z, Ye J. Berberine improves glucose metabolism through induction of glycolysis. Am J Physiol Endocrinol Metab 2008;294:E148-E156.

84. Xu M, Xiao Y, Yin J, Hou W, Yu X, Shen L, et al. Berberine promotes glucose consumption independently of AMP-activated protein kinase activation. PLoS One 2014;9(7):e103702.

85. Ren G, Wang YX, Li YH, Song DQ, Kong WJ, Jiang JD. Structure-activity relationship of berberine derivatives for their glucose-lowering activities. Int J Clin Exp Med 2017;10(3):50545060.

86. Cheng Z, Chen AF, Wu F, Sheng L, Zhang HK, Gu M, et al. 8, 8-Dimethyldihydroberberine with improved bioavailability and oral efficacy on obese and diabetic mouse models. Bioorg Med Chem 2010;18(16):5915-5924.

87. Muñoz GD, Dudley GB. Synthesis of 1, 2, 3, 4-tetrahydroquinolines including angustureine and congeneric alkaloids. A review. Org Prep Proced Int 2015;47(3):179-206.

88. Jacquemond-Collet I, Hannedouche S, Fabre N, Fourasté I, Moulis C. Two tetrahydroquinoline alkaloids from Galipea officinalis. Phytochemistry 1999;51(8):1167-1169.

89. Pan WH, Xu XY, Shi N, Tsang SW, Zhang HJ. Antimalarial activity of plant metabolites. Int J Mol Sci 2018;19(5):1382.

90. Anthony MP, Burrows JN, Duparc S, Moehrle J, Wells TN. The global pipeline of new medicines for the control and elimination of malaria. Malaria J 2012;11(1):316.

91. Schlitzer M. Antimalarial drugs-what is in use and what is in the pipeline. Archiv der Pharm 2008;341(3):149-163. 